\title{
PENGARUH KOMITE AUDIT TERHADAP KINERJA KEUANGAN PERUSAHAAN DENGAN DEWAN KOMISARIS SEBAGAI VARIABEL INTERVENING
}

\author{
Yunita Kurnia Shanti \\ Universitas Pamulang, Tangerang Selatan, Indonesia \\ kurniay25@gmail.com \\ https://doi.org/10.46367/iqtishaduna.v9i2.241
}

Received: Oct 12, 2020 Revised: Nov 5, 2020 Accepted: Nov 12, 2020 Published: Dec 17, 2020

\begin{abstract}
This study aims to examine the effect of the audit committee on the company's financial performance with the board of commissioners as an intervening variable in manufacturing companies in the consumer goods sector in 2016-2018. The population in this study is the manufacturing companies in the consumer goods sector which are listed on the Indonesia stock exchange in the 2016-2018 periods. The sampling method uses purposive sampling, which is a sampling technique with certain considerations or criteria. The number of samples obtained that can be processed is 90 samples. The data analysis method used is path analysis which has previously gone through a classic assumption test, testing is done directly and indirectly. The results of this study indicate the audit committee directly and significantly influences the company's financial performance. Both audit committees have an indirect and significant effect on the company's financial performance with the board of commissioners as an intervening variable. This shows that the calculation of the beta coefficient directly is greater than the indirect beta coefficient which is $0.230>0.05552$. This result means that the board of Commissioners variable cannot be an intervening variable of the audit committee on financial performance, because the effective supervisory function in evaluating the results of internal and external audits on the presentation of financial statements becomes the role of the audit committee.
\end{abstract}

Keywords: Audit Committee, Financial Performance, Board of Commissioners

\begin{abstract}
ABSTRAK
Penelitian ini bertujuan untuk menguji pengaruh komite audit terhadap kinerja keuangan perusahaan dengan dewan komisaris sebagai variabel intervening pada perusahaan manufaktur sektor barang konsumsi tahun 2016-2018. Populasi dalam penelitian ini adalah perusahaan manufaktur sektor barang konsumsi yang terdaftar di bursa efek Indonesia periode 2016-2018. Metode pengambilan sampel menggunakan purposive sampling, yang merupakan teknik penentuan sampel dengan pertimbangan atau kriteria tertentu. Jumlah sampel diperoleh yang bisa diolah adalah 90 sampel. Metode analisis data yang digunakan adalah path analysis atau analisis jalur yang sebelumnya telah melalui uji asumsi klasik. komite audit secara langsung dan signifikan mempengaruhi kinerja keuangan perusahaan. Komite audit memiliki pengaruh tidak langsung dan signifikan
\end{abstract}


terhadap kinerja keuangan perusahaan dengan dewan komisaris sebagai variabel intervening. Hasil ini ditunjukkan dengan hasil perhitungan koefisien beta secara langsung lebih besar dari koefisien beta tidak langsung yaitu 0,230>0,05552. Hasil ini berarti bahwa variabel dewan komisaris tidak dapat menjadi variabel intervening dari komite audit terhadap kinerja keuangan, karena fungsi pengawasan yang efektif dalam mengevaluasi hasil audit internal dan eksternal pada penyajian laporan keuangan menjadi peran komite audit sehingga secara langsung mempengaruhi kinerja keuangan perusahaan.

Kata Kunci: Komite audit, Kinerja Keuangan Perusahaan, Dewan Komisaris.

\section{PENDAHULUAN}

Laporan keuangan merupakan media yang juga digunakan untuk menilai kondisi perusahaan apakah dalam kondisi yang sehat ataupun buruk sehingga bisa digunakan sebagai dasar pengambilan keputusan. Tujuan laporan keuangan adalah untuk memberikan informasi kepada pihak luar perusahaan mengenai posisi keuangan, kinerja keuangan dan arus kas entitas yang bermanfaat bagi pengguna laporan untuk mengambil keputusan ekonomi sesuai dengan kebutuhan pengguna laporan keuangan (IAI 2015, 1.3). Informasi yang digunakan dalam mengukur kinerja keuangan adalah informasi keuangan, akuntansi manajemen informasi, dan informasi akuntansi keuangan seperti laba sebelum pajak, laba atas investasi dan sebagainya. Laporan keuangan dapat diperoleh dari arsip-arsip perusahaan yang dipublikasikan misalnya dalam annual report dan laporan keuangan tahunan. Annual report berisi informasi-informasi mengenai perusahaan seperti dewan komisaris, dewan direksi, komite audit, sekretaris perusahaan, laporan keuangan dan lain-lain.

Dalam melaksanakan Corporate Governance, dewan komisaris memegang peranan yang sangat penting dalam perusahaan. Fungsi dari dewan komisaris adalah mengawasi kelengkapan dan kualitas informasi laporan atas kinerja dewan direksi (Sukandar and Rahardja 2014). Salah satu contoh kasus penurunan laba yang belum lama terjadi di Indonesia adalah penurunan laba pada PT Wismilak Inti Makmur Tbk (WIIM) tahun 2017 (Putriadita 2018).

Dewan komisaris juga bertugas untuk memastikan bahwa manajemen telah benar-benar bekerja demi kepentingan perusahaan sesuai strategi yang telah ditetapkan serta menjaga kepentingan para pemegang saham, yaitu untuk meningkatkan nilai ekonomis perusahaan (Harimukti et al. 2016). Dewan komisaris harus selalu hadir dalam rapat yang dilakukan agar informasi yang diperoleh tidak terlewat dan dapat mengetahui adanya masalah yang terjadi sehingga dapat dengan mudah dalam menangani permasalahan yang ada.

Dalam rangka mewujudkan pengawasan yang efektif dalam menjalankan tugasnya, dewan komisaris perlu dibantu oleh komite audit yang bertugas menilai pelaksanaan kegiatan serta hasil audit yang dilakukan oleh satuan pengawasan internal maupun auditor eksternal, memberikan rekomendasi mengenai penyempurnaan sistem pengendalian manajemen menurut Effendi (2016, 51). Keberadaan komite audit juga sangat penting untuk kelangsungan hidup perusahaan. Komite audit pada umumnya memiliki akses langsung dengan setiap unsur pengendalian dalam perusahaan. Sehingga diperlukan suatu mekanisme 
komunikasi antara Komite audit dengan berbagai pihak, dengan kata lain semakin lancar komunikasi akan semakin meningkat kinerja dari pengendalian perusahaan (Effendi 2016, 59).

Kinerja keuangan perusahaan disini dapat diukur dengan menggunakan rasio profitabilitas yaitu Return on Assets (ROA). ROA menunjukan kemampuan perusahaan untuk menggunakan seluruh aset yang dimiliki agar bisa menghasilkan laba setelah pajak menurut Sudana (2011, 22). Menurut Putra (2015) rasio ini penting bagi pihak manajemen perusahaan untuk mengevaluasi efektifitas dan efisiensi manajemen perusahaan dalam mengelola seluruh aset perusahaan karena semakin baik ROA maka perusahaan semakin efisien dalam menggunakan aset perusahaan (Nuryanto et al. 2014). Untuk mengukur ROA kita membutuhkan informasi yang ada di dalam laporan keuangan.

Beberapa penelitian terdahulu terkait dengan variabel yang digunakan seperti penelitian yang dilakukan oleh Yuliani and Sukirno (2018) bahwa komite audit berpengaruh terhadap kinerja keuangan perusahaan, karena komite audit bertugas membantu dewan komisaris untuk memonitor proses pelaporan keuangan oleh manajemen, tetapi tidak sesuai dengan hasil penelitian dari Aini et al. (2017) dan Widyati (2013) yang menyatakan komite audit tidak berpengaruh secara signifikan terhadap kinerja keuangan perusahaan. Penelitian yang dilakukan oleh Harimukti et al. (2016) dan Rahmawati et al. (2017) bahwa dewan komisaris berpengaruh terhadap kinerja keuangan perusahaan, karena banyaknya jumlah anggota dewan komisaris dapat memberikan pengawasan yang lebih baik, tetapi hasil ini tidak sesuai dengan hasil penelitian yang dilakukan oleh Sukandar and Rahardja (2014) serta Putra (2015) yang menyatakan dewan komisaris tidak berpengaruh terhadap kinerja keuangan perusahaan. Berdasarkan teori tersebut maka penulis ingin melakukan penelitian apakah komite audit dapat berpengaruh secara langsung ataupun tidak langsung terhadap kinerja perusahaan dengan dewan komisaris sebagai variable intervening pada perusahaan manufaktur sektor barang konsumsi tahun 2016-2018.

\section{TELAAH LITERATUR}

\section{Teori Keagenan}

Dalam Rahmawati et al. (2017) bahwa Jensen dan Meckling pada tahun 1976 mendefinisikan teori keagenan sebagai hubungan antara agen (manajemen suatu usaha) dan prinsipal (pemilik usaha). Dalam hubungan keagenan terdapat suatu kontrak antara prinsipal yang menyewa orang lain atau agen untuk melaksanakan jasa dan mengambil keputusan yang telah didelegasikan kepadanya. Sehingga dalam hubungan keagenan, manajemen diharapkan dalam mengambil kebijakan perusahaan terutama kebijakan keuangan yang menguntungkan pemilik perusahaan. Bila keputusan manajemen merugikan bagi pemilik perusahaan maka akan timbul masalah keagenan. Dalam upaya mengatasi atau mengurangi masalah keagenan ini menimbulkan biaya keagenan yang akan ditanggung baik oleh principal maupun agent.

Dalam teori tersebut dijelaskan bahwa membagi biaya keagenan ini menjadi monitoring cost, bonding cost dan residual loss. Monitoring cost adalah biaya yang timbul dan ditanggung oleh principal untuk memonitor perilaku agen, yaitu untuk mengukur, mengamati, dan mengontrol perilaku agent. Bonding cost 
merupakan biaya yang ditangung oleh agent untuk menetapkan dan mematuhi mekanisme yang menjamin bahwa agent akan bertindak untuk kepentingan principal. Selanjutnya residual loss merupakan pengorbanan yang berupa berkurangnya kemakmuran principal sebagai akibat dari perbedaan keputusan agent dan keputusan principal.

Berdasarkan teori diatas, maka dalam penelitian ini teori agensi terdapat salah satu cara untuk mengukur tata kelola perusahaan yang baik yaitu dengan efektivitas dari organ perusahaan yaitu menggunakan Komite audit dan dewan komisaris untuk mengukur tata kelola perusahaan yang baik. Sedangkan untuk mengukur kinerja keuangan yang baik dalam perusahaan menggunakan Return on Assets.

Dalam Rahmawati et al. (2017) bahwa Forum For Corporate Governance Indonesia (2001) Good Corporate Governance (GCG) merupakan seperangkat peraturan yang mengatur hubungan antara pemegang saham, pengurus perusahaan, pihak kreditur, pemerintah, karyawan serta para pemegang kepentingan internal dan eksternal lainnya untuk mengendalikan perusahaan. Tujuan GCG antara lain untuk meningkatkan pengelolaan perusahaan dan fungsi kemandirian organ-organ perusahaan. Dewan komisaris dan komite audit mempunyai peranan yang sangat penting dan strategis dalam memelihara kredibilitas proses penyusunan laporan keuangan menurut Yuliani and Sukirno (2018).

\section{Komite Audit}

Setiap perusahaan di Indonesia diwajibkan untuk membentuk komite audit yang dibentuk oleh dewan komisaris melalui suatu surat keputusan dewan komisaris. Komite audit merupakan suatu komite yang bekerja secara profesional dan independen yang dibentuk oleh dewan komisaris. Tugasnya adalah membantu dan memperkuat fungsi dewan komisaris atas proses pelaporan keuangan, manajemen risiko, pelaksanaan audit, dan implementasi dari corporate governance di perusahaan-perusahaan menurut Puradiredja (2016, 4). Perusahaan publik wajib membentuk komite audit yang bekerja secara kolektif dan berfungsi untuk mambantu dewan komisaris dan dewan pengawas dalam melaksanakan tugasnya. Komite audit minimal memiliki 3 orang anggota yang tediri dari ketua komite audit dan 2 orang anggota yang merupakan pihak eksternal yang independen. Dalam penelitian ini menggunakan jumlah anggota komite audit sebagai proksi dari komite audit. Jumlah anggota komite audit digunakan untuk mengukur efektivitas komite audit terhadap kinerja keuangan perusahaan.

\section{Dewan Komisaris}

Dewan Komisaris merupakan organ perusahaan yang bertugas dan bertanggung jawab secara kolektif untuk melakukan pengawasan dan memberikan nasihat kepada Direksi. Menurut Effendi $(2016,26)$ dewan komisaris dipilih oleh pemegang salam dalam Rapat Umum Pemegang Saham (RUPS) yang mewakili kepentingan pemegang saham tersebut. Peran Komisaris juga sangat penting dan cukup menentukan bagi keberhasilan implementasi GCG. Perusahaan publik wajib memiliki dewan komisaris yang minimal terdiri dari 2 orang anggota komisaris, salah satu diantaranya adalah komisaris independen. Dewan komisaris bertanggung jawab untuk melakukan tugas pengawasan dan pemberi nasihat 
kepada dewan direksi untuk kepentingan perseroan dan sesuai dengan tujuan perseroan. Dalam penelitian ini menggunakan jumlah anggota dewan komisaris sebagai proksi dari dewan komisaris. Jumlah anggota dewan komisaris digunakan untuk mengukur efektivitas dewan komisaris terhadap kinerja keuangan perusahaan.

\section{Kinerja Keuangan Perusahaan}

Menurut Munawir (2010, 30), kinerja keuangan perusahaan merupakan satu diantara dasar penilaian mengenai kondisi keuangan perusahaan yang dilakukan berdasarkan analisa terhadap rasio keuangan perusahaan. Pihak yang berkepentingan sangat memerlukan hasil dari pengukuran kinerja keuangan perusahaan untuk dapat melihat kondisi perusahaan dan tingkat keberhasilan perusahaan dalam menjalankan kegiatan operasionalnya. Menurut Munawir (2010, 67), selain membandingkan rasio keuangan dengan standar rasio, kinerja keuangan juga dapat dinilai dengan membandingkan rasio keuangan tahun yang dinilai dengan rasio keuangan pada tahun-tahun sebelumnya. Dengan membandingkan rasio keuangan pada beberapa tahun penilaian dapat dilihat bagaimana kemajuan ataupun kemunduran kinerja keuangan sesuai dengan kegunaan masing-masing rasio tersebut. Dalam penelitian ini menggunakan Return on Assets (ROA) sebagai proxy kinerja keuangan. Informasi yang digunakan untuk menghitung ROA diperoleh dari laporan laba rugi dan laporan posisi keuangan. ROA Menunjukan kemampuan perusahaan untuk menggunakan seluruh aset yang dimiliki agar bisa menghasilkan laba setelah pajak menurut Sudana $(2011,22)$. Rasio ini merupakan perbandingan antara laba bersih dengan total aset. Rasio ini menunjukkan berapa besar laba bersih diperoleh perusahaan bila diukur dari nilai asetnya. Rumus yang digunakan adalah sebagai berikut:

$$
\text { Return on Assets }=\frac{\text { LabaBersih }}{\text { TotalAset }}
$$

\section{Kerangka Pemikiran}

Menurut Sugiyono $(2017,60)$ kerangka berpikir dalam suatu penelitian perlu di kemukakan apabila berkenaan dua variabel atau lebih. Kerangka pemikiran merupakan penjelasan yang bersifat sementara terhadap gejala-gejala yang menjadi obyek penelitian. Oleh sebab itu didalam penelitian ini disajikan kerangka pemikiran mengenai variabel komite audit, dewan komisaris dan kinerja keuangan perusahaan. Sehingga dalam penelitian ini dapat dikembangkan hipotesis yang digunakan untuk mengukur pengaruh secara langsung dan pengaruh tidak langsung yaitu:

H1: Komite audit berpengaruh secara langsung dan signifikan terhadap kinerja keuangan perusahaan.

H2: Komite audit berpengaruh secara signifikan terhadap dewan komisaris.

H3: Dewan komisaris berpengaruh secara signifikan terhadap kinerja keuangan perusahaan.

\section{METODE PENELITIAN}

Jenis penelitian ini menggunakan jenis penelitian kuantitatif dengan data sekunder. Menurut Sugiyono $(2017,8)$ metode kuantitatif merupakan metode 
penelitian yang berlandaskan pada filsafat positivisme, digunakan untuk meneliti pada populasi atau sampel tertentu, pengumpulan data menggunakan instrumen penelitian, analisis data bersifat kuantitatif statistik, dengan tujuan untuk menguji hipotesis yang telah ditetapkan. Populasi dalam penelitian ini adalah seluruh perusahaan yang masuk dalam sektor barang konsumsi dan terdaftar di Bursa Efek Indonesia pada tahun 2016-2018, yaitu sebanyak 41 perusahaan terdaftar. Sampel yang digunakan dalam penelitian ini diambil dengan menggunakan pendekatan purposive sampling yang merupakan teknik penentuan sampel dengan pertimbangan tertentu menurut Sugiyono (2017, 85). Adapun kriteria atau pertimbangan pengambilan sampel yang digunakan penulis adalah: (1) Perusahaan manufaktur sub sektor barang konsumsi yang telah terdaftar di Bursa Efek Indonesia (BEI) sebelum tanggal 31 Desember 2016-2018. (2) Perusahaan menerbitkan annual report secara lengkap kepada Bursa Efek Indonesia dan dipublikasikan di website resmi BEI periode 2016-2018. (3) Perusahaan tidak mengalami delesting selama periode 2016-2018. Berdasarkan kriteria pengambilan sampel diatas, terdapat 30 perusahaan yang memenuhi kriteria tersebut sehingga diperoleh total sampel dalam tahun amatan sebanyak 90.

\section{Variabel dan Pengukuran}

Varibel-variabel dalam penelitian ini diklasifikasikan menjadi 3 yaitu variabel dependen, variabel independen dan variabel intervening. Variabel tersebut antara lain: (1) Variabel komite audit adalah komite audit yang digunakan untuk mengukur seberapa efektif komite audit dalam mengawasi kinerja perusahaan melalui laporan keuangan. Indikatir variabel komite audit menurut Rahmawati et al. (2017) diukur menggunakan jumlah anggota komite audit, yaitu komite audit $=\Sigma$ anggota komite audit. (2) Dewan komisaris digunakan untuk mengukur seberapa efektif dewan komisaris dalam mengawasi kinerja perusahaan. Perhitungan dewan komisaris menurut Rahmawati et al. (2017) adalah sebagai berikut komite audit $=\Sigma$ anggota dewan komisaris. (3) Kinerja keuangan sebagai variabel dependen adalah variabel yang dipengaruhi atau yang menjadi akibat, karena adanya variabel bebas Sugiyono (2017, 39). Variabel dependen dalam penelitian ini adalah kinerja keuangan perusahaan yang digunakan untuk mengukur seberapa baik kinerja perusahaan dari segi kinerja keuangan perusahaan tersebut. Menurut Putra (2015), rumus yang digunakan untuk menghitung ROA sebagai berikut:

$$
\mathrm{ROA}=\frac{\text { Lababersih setelah pajak }}{\text { Total Aset }}
$$

\section{Metode Analisis Data}

Metode analisis data yang digunakan adalah path analysis atau analisis jalur yang sebelumnya sudah melalui uji asumsi klasik, permasalahan yang memiliki karakteristik hubungan berjenjang dan jenis variabel semacam ini memerlukan teknik analisis yang dapat menggunakan persamaan silmutanus dengan teknik estimasi analisis jalur (Kuncoro and Ridwan 2012). 


\section{HASIL DAN PEMBAHASAN PENELITIAN}

\section{Uji Statistik Deskriptif}

\section{Tabel 1 Uji Statistik Deskriptif Descriptive Statistics}

\begin{tabular}{l|r|r|r|r|r} 
& N & Minimum & Maximum & Mean & Std. Deviation \\
\hline Komite Audit & 90 & 2.00 & 4.00 & 2.9778 & .33446 \\
\hline Dewan Komisaris & 90 & 2.00 & 8.00 & 4.2333 & 1.62183 \\
\hline Kinerja Keuangan & 90 & -.10 & .26 & .0749 & .06433 \\
\hline Valid N (listwise) & 90 & & & & \\
\hline
\end{tabular}

Berdasarkan hasil uji statistik deskriptif pada Tabel 1 diperoleh 90 data. Hasil analisis terhadap komite audit dengan nilai minimum 2, nilai maksimum 4, nilai mean 2,97 dan standar deviasi 0,334. Hasil analisis terhadap Dewan Komisaris dengan nilai minimum 2, nilai maksimum 8, nilai mean 4,23 dan standar deviasi 1,621. Hasil analisis terhadap Kinerja Keuangan Perusahaan dengan nilai minumum $-0,10$, nilai maksimum 0,26 , nilai mean 0,0749 dan standar deviasi 0,0643.

\section{Uji Normalitas}

Uji normalitas dilakukan menggunakan uji Kolmogorov-Smirnov $(K-S)$. Hipotesis Nol (Ho) yaitu data berdistribusi secara normal dan hipotesis alternatif (Ha) yaitu data tidak berdistribusi secara normal menurut Ghozali $(2018,30)$. Nilai K-S unstandardized residual test statistic pada Tabel 20,69 dengan probabilitas signifikansi asymp. sig. 0,200, ini berarti Ha ditolak atau Ho diterima, artinya semua variabel datanya terdistribusi secara normal.

Tabel 2 Uji Normalitas

\section{One-Sample Kolmogorov-Smirnov Test}

\begin{tabular}{llr} 
& & $\begin{array}{r}\text { Unstandardiz } \\
\text { ed Residual }\end{array}$ \\
\hline $\mathrm{N}$ & & 90 \\
\hline Normal Parameters & Mean & .0000000 \\
\cline { 2 - 3 } & Std. Deviation & .06260779 \\
\hline Most Extreme Differences & Absolute & .069 \\
\cline { 2 - 3 } & Positive & .069 \\
\cline { 2 - 3 } & Negative & -.041 \\
\hline Test Statistic & & .069 \\
\hline Asymp. Sig. (2-tailed) & & $.200^{\mathrm{c}, \mathrm{d}}$ \\
\hline
\end{tabular}

a. Test distribution is Normal.

b. Calculated from data.

c. Lilliefors Significance Correction.

d. This is a lower bound of the true significance. 


\section{Uji Heteroskedastisitas}

Tabel 3 Uji Heteroskedastisitas

\begin{tabular}{|c|c|c|c|c|c|c|}
\hline \multicolumn{7}{|c|}{ Coefficients $^{a}$} \\
\hline \multirow[b]{2}{*}{ Model } & & \multicolumn{2}{|c|}{ Unstandardized Coefficients } & \multirow{2}{*}{$\begin{array}{c}\text { Standardized } \\
\text { Coefficients } \\
\text { Beta }\end{array}$} & \multirow[b]{2}{*}{$t$} & \multirow[b]{2}{*}{ Sig. } \\
\hline & & B & Std. Error & & & \\
\hline \multirow[t]{2}{*}{1} & (Constant) & .021 & .037 & & .580 & .563 \\
\hline & Komite Audit & .009 & .012 & .079 & .746 & .458 \\
\hline
\end{tabular}

Salah satu ukuran utuk menentukan ada atau tidaknya masalah heteroskedastisitas dapat menggunakan dapat menggunakan tingkat signifikansi, dikatakan tidak terjadi gejala heteroskedastisitas jika nilai signifikansi yang diperoleh lebih dari 0,05 (Sunyoto 2013). Hasil uji diperoleh nilai signifikasi lebih dari 0,05 atau sebesar 0,458 artinya tidak terjadi gejala heteroskedastisitas.

\section{Uji Autokorelasi}

\begin{tabular}{|c|c|c|c|c|c|}
\hline \multicolumn{6}{|c|}{$\begin{array}{c}\text { Tabel } 3 \text { Uji Autokorelasi } \\
\text { Model Summary }\end{array}$} \\
\hline Model & $\mathrm{R}$ & R Square & $\begin{array}{l}\text { Adjusted R } \\
\text { Square }\end{array}$ & $\begin{array}{l}\text { Std. Error of } \\
\text { the Estimate }\end{array}$ & $\begin{array}{l}\text { Durbin- } \\
\text { Watson }\end{array}$ \\
\hline 1 & $.230^{\mathrm{a}}$ & .053 & .042 & .06296 & 1.208 \\
\hline
\end{tabular}

a. Predictors: (Constant), Komite Audit

b. Dependent Variable: Kinerja Keuangan

Salah satu ukuran utuk menentukan ada atau tidaknya masalah autokorelasi dapat menggunakan uji Durbin Watson (DW). Dikatakan tidak terjadi autokorelasi jika nilai DW berada diantara -2 dan +2 atau $-2<$ DW $<+2$ (Sunyoto 2013). Hasil uji autokorelasi menunjukkan nilai DW berada diantara -2 dan +2 yaitu $-2<1,208<+2$, sehingga dilihat dari hasilnya menjelaskan tidak terjadi autokorelasi.

\section{Uji Hipotesis Analisis Jalur}

Tabel 4 Uji Hipotesis Pertama Secara Langsung Coefficients $^{\mathrm{a}}$

\begin{tabular}{|c|c|c|c|c|c|c|}
\hline \multirow[b]{2}{*}{ Model } & & \multicolumn{2}{|c|}{ Unstandardized Coefficients } & \multirow{2}{*}{$\begin{array}{c}\text { Standardized } \\
\text { Coefficients } \\
\text { Beta } \\
\end{array}$} & \multirow[b]{2}{*}{$\mathrm{t}$} & \multirow[b]{2}{*}{ Sig. } \\
\hline & & $\mathrm{B}$ & Std. Error & & & \\
\hline \multirow[t]{2}{*}{1} & (Constant) & -.057 & .060 & & -.949 & .345 \\
\hline & Komite Audit & .044 & .020 & .230 & 2.215 & .029 \\
\hline
\end{tabular}

a. Dependent Variable: Kinerja Keuangan

Uji hipotesis secara langsung dengan analisis jalur menjelaskan pengaruh langsung komite audit (X1) terhadap kinerja keuangan perusahaan (Y) dengan 
nilai koefisien sebesar 0.230 pada Tabel 4 .

Tabel 5 Uji Hipotesis Kedua Secara Tidak Langsung Coefficients $^{\mathrm{a}}$

\begin{tabular}{|c|c|c|c|c|c|c|}
\hline \multirow[b]{2}{*}{ Model } & & \multicolumn{2}{|c|}{ Unstandardized Coefficients } & \multirow{2}{*}{$\begin{array}{c}\text { Standardized } \\
\text { Coefficients } \\
\text { Beta }\end{array}$} & \multirow[b]{2}{*}{$t$} & \multirow[b]{2}{*}{ Sig. } \\
\hline & & B & Std. Error & & & \\
\hline \multirow[t]{2}{*}{1} & (Constant) & 1.103 & 1.512 & & .729 & .468 \\
\hline & Komite Audit & 1.051 & .505 & .217 & 2.083 & .040 \\
\hline
\end{tabular}

a. Dependent Variable: Dewan Komisaris

Tabel 6 Uji Hipotesis Ketiga Secara Tidak Langsung Coefficients $^{\mathrm{a}}$

\begin{tabular}{|c|c|c|c|c|c|c|}
\hline \multirow[b]{2}{*}{ Mode } & & \multicolumn{2}{|c|}{ Unstandardized Coefficients } & \multirow{2}{*}{$\begin{array}{c}\text { Standardized } \\
\text { Coefficients } \\
\text { Beta }\end{array}$} & \multirow[b]{2}{*}{$t$} & \multirow[b]{2}{*}{ Sig. } \\
\hline & & $\mathrm{B}$ & Std. Error & & & \\
\hline \multirow[t]{2}{*}{1} & (Constant) & .032 & .019 & & 1.724 & .088 \\
\hline & Dewan Komisaris & .010 & .004 & .256 & 2.484 & .015 \\
\hline
\end{tabular}

a. Dependent Variable: Kinerja Keuangan

Hasil pengujian hipotesis secara tidak langsung dengan analisis jalur menjelaskan pengaruh komite audit (X1) melalui variable intervening dewan komisaris $(\mathrm{Z})$ terhadap nilai perusahaan $(\mathrm{Y})$ diperoleh nilai koefisien adalah sebesar 0.217 x $0.256=0.055552$.

\section{Pengujian Secara Langsung}

Hipotesis pertama, komite audit berpengaruh langsung dan signifikan terhadap kinerja keuangan perusahaan. Tabel 4 menunjukkan bahwa koefisien beta dari regresi pengaruh komite audit terhadap kinerja keuangan perusahaan sebesar 0.230 dengan signifikansi 0.029 , signifikansi < dari 0.050 maka komite audit berpengaruh signifikan dan koefisien beta yang lebih besar dari 0 menyatakan pengaruhnya positif secara langsung terhadap kinerja keuangan, artinya hipotesis pertama diterima. Komite audit berpengaruh secara signifikan terhadap kinerja keuangan. Hasil penelitian ini sesuai dengan penelitian yang dilakukan oleh Yuliani and Sukirno (2018) yang artinya jumlah anggota komite audit sudah dapat memaksimalkan pengawasan dalam penyajian laporan keuangan. Setiap perusahaan yang sudah terdaftar di BEI telah menerapkan standar mengenai jumlah anggota komite audit telah sesuai dengan peraturan yang berlaku. Fungsi pengawasan yang dilakukan komite audit dengan baik dapat meningkatkan kualitas laporan keuangan perusahaan.

\section{Pengujian Secara Tidak Langsung}

Hipotesis kedua, komite audit berpengaruh signifikan terhadap dewan komisaris. Tabel 5 menunjukkan bahwa koefisien beta dari regresi pengaruh 
struktur modal terhadap profitabilitas sebesar 0.217 dengan signifikansi 0.04, dengan signifikansi < dari 0.050 maka komite audit mempunyai pengaruh signifikan terhadap dewan komisaris dan koefisien beta yang lebih besar dari 0 yaitu 0.217 , maka pengaruhnya adalah positif terhadap dewan komisaris, artinya hipotesis kedua diterima. Dalam melaksanakan tugasnya secara efektif dewan komisaris perlu dibantu oleh komite audit yang bertugas melakukan pengawasan dan menilai pelaksanaan kegiatan serta hasil audit yang dilakukan oleh satuan pengawasan atau auditor internal maupun auditor eksternal dalam memberikan rekomendasi mengenai penyempurnaan sistem pengendalian manajemen menurut Effendi $(2016,51)$.

Hipotesis ketiga, dewan komisaris berpengaruh signifikan terhadap kinerja keuangan perusahaan. Tabel 6 menunjukkan koefisien beta dari regresi pengaruh profitabilitas terhadap nilai perusahaan sebesar 0.256 dengan signifikansi 0.015 , signifikansi $<0.050$ maka dewan komisaris berpengaruh signifikan dan koefisien beta yang lebih besar dari 0 menyatakan pengaruhnya positif terhadap nilai perusahaan, artinya hipotesis ketiga diterima. Hasil ini sesuai dengan penelitian yang dilakukan oleh Harimukti et al. (2016) dan Rahmawati et al. (2017). Dewan komisaris berpengaruh secara signifikan terhadap kinerja keuangan perusahaan. Jumlah dari anggota dewan komisaris dinilai dapat memaksimalkan fungsi dari pengawasan atas kinerja dewan direksi termasuk penyajian laporan keuangan serta berperan penting dalam pengambilan keputusan. Hampir setiap perusahaan yang sudah terdaftar di BEI telah menerapkan standar mengenai jumlah anggota dewan komisaris sesuai dengan standar yang berlaku yaitu minimal 2 anggota, sehingga dewan komisaris lebih efektif dan efesien dalam menjalankan tugasnya.

Hasil pengujian hipotesis secara tidak langsung dengan analisis jalur menjelaskan pengaruh komite audit (X1) melalui variable intervening dewan komisaris $(\mathrm{Z})$ terhadap nilai perusahaan $(\mathrm{Y})$ diperoleh nilai koefisien yang lebih kecil daripada pengujian secara langsung yaitu sebesar $0.217 \times 0.256=0.055552$. Hal ini menunjukkan bahwa perhitungan koefisien beta secara langsung lebih besar daripada koefisien beta secara tidak langsung yaitu $0.230>0.05552$. Hasil ini berarti variable dewan komisaris tidak dapat menjadi variabel intervening dari komite audit terhadap kinerja keuangan, karena fungsi pengawasan yang efektif dalam hal menilai hasil audit internal dan eksternal pada penyajian laporan keuangan menjadi peran komite audit. Keberadaan komite audit juga sangat penting untuk kelangsungan hidup perusahaan terutama membantu peran dewan komisaris.

\section{KESIMPULAN}

Berdasarkan pembahasan hasil penelitian dapat disimpulkan bahwa komite audit berpangaruh secara langsung dan signifikan terhadap kinerja keuangan perusahaan (pengujian secara langsung), komite audit berpengaruh secara tidak langsung dan signifikan terhadap dewan komisaris (pengujian secara tidak langsung), dewan komisaris berpengaruh secara tidak langsung dan signifikan terhadap kinerja keuangan perusahaan. Perbandingan perhitungan koefisien beta secara langsung lebih besar daripada koefisien beta secara tidak langsung yaitu $0.230>0.05552$. Hasil ini berarti variabel dewan komisaris tidak dapat menjadi 
variabel intervening dari komite audit terhadap kinerja keuangan, karena fungsi pengawasan yang efektif dalam hal menilai hasil audit internal dan eksternal pada penyajian laporan keuangan menjadi peran komite audit.

\section{DAFTAR PUSTAKA}

Aini, Ayu Nur, Edi Budi Santoso dan Isnani. 2017. "Pengaruh Kepemilikan Istitusional, Proporsi Dewan Komisaris Independen, Komite Audit, Struktur Modal, Ukuran Perusahaan dan Leverage Terhadap Kinerja Keuangan (Studi Pada Perusahaan Manufaktur Sektor Industri Barang Konsumsi yang Terdaftar di BEI Tahun 2011-2015)". Jurnal Ilmiah Mahasiswa S1 Akuntansi 3 (3): 1-18.

Bursa Efek Indonesia. 2019. Diakses dari halaman website https://www.idx.co.id/. Effendi, Muh. Arief. 2016. The Power of Good Corporate Governance Teori dan Emplementasi Edisi 2. Jakarta: Salemba Empat.

Forum For Corporate Governance Indonesia. 2001. Peranan Dewan Komisaris dan Komite Audit dalam Pelaksanaan Corporate Governance (Tata Kelola Perusahaan). Diakses dari halaman website: https://www.fcgi.or.id/.

Ghozali, Imam. 2018. Aplikasi Analisis Multivariate dengan Program IBM SPSS. Semarang: Universitas Dipenogoro.

Harimukti, Wisma Tytus, Abdul Halim dan Ati Retna Sari. 2016. "Pengaruh Dewan Komisaris, Kepemilikan Institusional dan Leverage Terhadap Kinerja Keuangan (Studi Empiris pada Perusahaan Otomotif yang Terdaftar di Bursa Efek Indonesia Tahun 2013-2015)". Jurnal Riset Mahasiswa Akuntansi 4 (2).

Ikatan Akuntan Indonesia. 2015. Pernyataan Standar Akuntansi Keuangan (PSAK) No. 1 Tahun 2015 Tentang Penyajian Laporan Keuangan. Jakarta: Dewan Standar Akuntansi Keuangan.

Kasmir. 2015. Analisis laporan Keuangan. Jakarta: Rajawali.

Kuncoro, Achmad Engkos dan Ridwan. 2012, "Analisis Jalur (Path Analisis), Edisi kedua. Bandung: Penerbit Alfabeta.

Putriadita, Danielisa. 2018. Laba Wismilak pada 2017 Turun 61,8\%. Diakses dari halaman website kontan: https://investasi.kontan.co.id/news/labawismilak-pada-2017-turun-618.

Munawir, S. 2010. Analisis Laporan Keuangan, Edisi Keempat. Yogyakarta: Liberty.

Musta'an dan Herlina Kusuma Wardani. 2017. "Akuntansi Dari Kacamata Syariah Dan Ekonomi Islam”. Jurnal Ilmiah Ekonomi Islam 3 (03): 181185. http://dx.doi.org/10.29040/jiei.v3i03.130.

Nuryanto, Rahmat, Muhammad Tho'in dan Herlina Kusuma Wardani. 2014. "Rasio Likuiditas, Rasio Solvabilitas, Rasio Rentabilitas Koperasi Jasa Keuangan Syariah Di Jawa Tengah”. Jurnal Akuntansi dan Pajak 15 (01): 60-67. http://dx.doi.org/10.29040/jap.v15i01.144.

Otoritas Jasa Keuangan. 2015. Peraturan Otoritas Jasa Keuangan No. 55/POJK.04/2015 Tentang Pembentukan Pedoman Pelaksanaan Kerja Komite Audit. Jakarta. 
Puradiredja, Kanaka, (2006), "Manual Komite Audit". Jakarta: Ikatan Komite Audit Indonesia.

Putra, Brayen Prastika Dwi. 2015. "Pengaruh Dewan Komisaris, Proporsi Komisaris Independen Terhadap Kinerja Perusahaan", Jurnal Manajemen Teori dan Terapan 8 (2): 70-85.

Rahmawati, Inge, Brady Rikumahu dan Vaya Juliana Dillak. 2017. "Pengaruh Dewan Direksi, Dewan Komisaris, Komite Audit dan Corporate Social Responsibility Terhadap Kinerja Keuangan Perusahaan”. JAE: Jurnal $\begin{array}{lllll}\text { Akuntansi dan } & \text { Ekonomi }\end{array}$ https://doi.org/10.29407/jae.v2i2.866.

Sunyoto, Danang. 2013. Teori Kuesioner dan Proses Analisis Data Perilaku Organisasional. Yogyakarta: Caps Centre of Academic Publishing Service.

Sudana, I Made. 2011. Manajemen Keuangan Perusahaan Teori dan Praktik. Jakarta: Erlangga.

Sugiyono. 2017, Metode Penelitian Kuantitatif, Kualitatif, dan R\&D. Bandung: Alfabeta.

Sukandar, Panky Pradana dan Rahardja. 2014. "Pengaruh Dewan Direksi dan Dewan Komisaris Serta Ukuran Perusahaan Terhadap Kinerja Keuangan Perusahaan (Studi Empiris pada Perusahaan Manufaktur Sektor Consumer Good yang Terdaftar di BEI Tahun 2010-2012)”. Diponegoro Journal Of Accounting 3 (3): 1-7.

Widyati, Maria Fransisca. 2013. "Pengaruh Dewan Direksi, Komisaris Independen, Komite Audit, Kepemilikan Manajerial dan Kepemilikan Institusional Terhadap Kinerja Keuangan”. Jurnal Ilmu Manajemen (JIM) 1 (1): 234-249.

Yuliani, Nurul Rifa dan Sukirno. 2018. "Pengaruh Komisaris Independen, Komite Audit dan Rasio Leverage Terhadap Kinerja Keuangan Perusahaan". PROFITA: Kajian Ilmu Akuntansi 6 (8): 1-14. 